\title{
A VEZETŐ NÉLKÜLI JÁRMŰVEK ALKALMAZÁSÁNAK LEHETŐSÉGEI A KATONAI KÖZÚTI SZÁLLÍTÁSOKBAN
}

\author{
THE POSSIBLE USAGE OF UNMANNED VEHICLES IN MILITARY \\ TRANSPORTATION
}

\author{
VARGA Viktória \\ (ORCID: 0000-0002-1791-9254) \\ viktoriavarga777@gmail.com
}

\begin{abstract}
Absztrakt
A logisztikai támogatás, azon belül a közlekedési támogatás megfelelö szintü biztositása óriási szerepet játszik a katonai müveletek végrehajtása során. Az elmúlt pár évtizedben átalakult a hadviselés, a katonai közlekedés azonban lényegében nem változott az új kihívások ellenére sem. A forradalmi változást ezen a területen a vezetö nélküli jármüvek alkalmazása hozhatja el. A vezető nélküli jármüvek nagy fejlődést jelenthetnek a katonai szállitások területén, elsősorban a vegyes vagy teljesen autonóm jármüvekböl álló konvojok révén. Az autonóm gépjármüvekkel jelentösen csökken az emberi élet kockáztatása, emellett növekszik a müveleti rugalmasság, pozitív hatást gyakorol a döntéshozatali folyamatokra, illetve a szállitások tervezésére és szervezésére. Emellett gazdaságossági és környezetvédelmi szempontokból is kedvező tulajdonságokkal bírnak. Ugyanakkor a vezetö nélküli jármüvek igen modern technológiákat alkalmaznak a vezető helyettesitésére, de ezek a berendezések is meghibásodhatnak, és ki vannak téve a kibertámadások veszélyének. Tehát a vezető nélküli jármüvek katonai felhasználásának nem csupán elönyei vannak, hanem magában hordozza a kockázatokat is.
\end{abstract}

Kulcsszavak: vezető nélküli jármüvek, katonai közlekedés, autonóm jármü, katonai közúti szállitás

\begin{abstract}
Providing the appropriate logistical support within that movement and transportation plays an important role in successful military missions. The means and methods of our armed forces have been transformed due to the change in warfare during the last few decades, but military transportation remains the same in spite of the new challenges. Unmanned vehicles can be the revolutionary solution to this problem. Unmanned vehicles could be a crucial part of the improvement of military transportation. On the one hand using autonomous vehicles for transportation has a huge impact on risking human life, on the other hand they increase the level of operational flexibility. In addition, they influence the decision making process and transportation planning and coordination in a positive way. Operating unmanned vehicles instead of traditional ones is significantly better from the point of view of economy and the protection of the environment. In spite the fact that unmanned vehicles contain precise and modern technologies in order to substitute the human driver, these devices can go wrong or get damaged anytime. So operating unmanned vehicles in military transportation has not only advantages it also carries the risk.
\end{abstract}

Keywords: unmanned vehicles, military transportation, autonomous vehicle, military road transportation 


\section{BEVEZETÉS}

Az emberi civilizáció kialakulásával együtt járt a közlekedés fejlödése is. Már évezredekkel ezelőtt kiépültek az első úthálózatok és folyamatosan újabb és újabb járművek jelennek meg rajtuk. Legyenek bármilyen kezdetlegesek vagy modernek az utóbbi eszközök, egy közös bennük - az ember, mint vezető. Napjainkra azonban a technológia elérte azt a szintet, hogy a humán tényező teljesen vagy részben kihagyhatóvá vált a gépjármü irányításából. Ezek az önvezető jármüvek sorsdöntő változásokat hozhatnak mind a civil, mind a katonai közlekedésben. Megoldásra kerülhetnek olyan problémák, mint a soförhiány, valamint növekedhet a katonai közlekedés biztonsága, miközben az emberélet kockáztatása csökkenhet. Az előnyökön túl azonban megjelenhetnek negatívumok is, melyeket nem lehet figyelmen kívül hagyni.

Az autonóm jármủvek mủveleti területen történő felhasználása gazdaságossági és biztonsági szempontból is sok előnnyel jár, mivel a közvetlen emberi irányítás mellőzése nagyfokú rugalmasságot eredményez többek között a döntéshozatal és a szállításszervezés területén. Célom, hogy bemutassam a vezető nélküli szállító jármüvek felhasználásának lehetőségeit a katonai mủveletek során, részletezem a katonai alkalmazhatóságot meghatározó tényezőket, valamint a használatból származó előnyöket és hátrányokat. A téma aktualitásának másik oka, hogy bár a civil felhasználás tekintetében számtalan magyar és idegen nyelvü tanulmánnyal találkozhatunk, a vizsgált területen - az önvezető szárazföldi szállítójárművek katonai célú igénybevétele - kevés a magyar nyelvü szakirodalom. Ezért arra törekszem, hogy a külföldi irodalom tanulmányozása alapján egy összefoglalást adjak a vezető nélküli szállítójármütechnológia katonai vonatkozásairól.

\section{A VEZETŐ NÉLKÜLI JÁRMŰVEK KATONAI ALKALMAZÁSÁT MEGHATÁROZÓ TÉNYEZÖK}

A katonai és civil szállításokat összehasonlítva sok egyezést állapíthatunk meg, de több olyan jellemzője is van a katonai alkalmazásnak, amelyek sajátos követelményeket támasztanak a jármüveket, az alkalmazott technológiát illetően. A katonai szállítások egy része ugyanolyan módon, ugyanazon úthálózat igénybe vételével, hasonló járművekkel zajlik, mint a civil szállításoknál. A katonai felhasználásnak azonban vannak olyan területei, amikor a szállítójárműveknek a civil használattól eltérő, speciális körülményekkel kell megbirkózniuk. A sajátosság adódhat egyrészt a müveleti környezetből, a fegyveres konfliktusokat jellemző, folyamatosan változó helyzetböl, illetve ilyen körülmények között egy balesetnek vagy incidensnek is más jelentősége van, mint a civil szférában.

A katonai müveletek sokszor a lakott területektől, illetve a kiépített úthálózattól távol, változatos terepviszonyok között zajlanak. De még a települések környezetében sem biztos, hogy megfelelő az utak minősége, gyakran épp a konfliktusok során rongálódik meg a közlekedési infrastruktúra. A katonai mozgásokat attól függetlenül végre kell tudni hajtani, hogy az adott helyszínen ki van-e építve a közúthálózat vagy sem. Azokon a területeken, ahol a nehéz terep olyan domborzati viszonyokkal találkozik, amelyek korlátozzák az egymás mellett elférö járművek számát, ott az autonóm járművek előnyt jelenthetnek. Példaként említhető az Iraki háború ${ }^{1}$, ahol az ilyen szük szakaszokon gyakran alakultak kiközlekedési dugók, melyek lassították, sőt veszélyeztették is a müveletek biztonságos végrehajtását. Ennek oka az volt, hogy a jármüvek vezetői nem mérték fel jól az adott útszakasz korlátait, az ott közlekedő más egységek mozgását. A vezető nélküli jármükonvojokkal a közlekedési fegyelem

\footnotetext{
${ }^{1}$ Operation Iraqi Freedom: 2003 - 2011.
} 
hiányából és a nem összehangolt mozgásokból eredő problémák elkerülhetők lettek volna. [1; pp. 15.]

A katonai müveletek során sokkal több és intenzívebb inger, hatás éri a soföröket, mint a civil életben. A rugalmasság olyan tényezö, amely minden területen nélkülözhetetlen a siker eléréséhez, de a katonai feladatok végrehajtása során emberek életét mentheti meg. A müveleti területen az alakulatok általában folyamatos mozgásban vannak és az állandóan változó környezet megnehezíti a katonai közlekedés lebonyolítását. Az autonóm jármüveknek ezekhez a körülményekhez alkalmazkodva kell biztosítani az utánpótlást. [1; pp. 4-7.] A vezető nélküli járművek felhasználása müveleti területen fokozhatja a rugalmasságot. Egy menet végrehajtása során ugyanis gyakran kell szembenéznie a gépjármüvezetőnek váratlanul fellépő helyzetekkel, támadásokkal, útakadályokkal, ilyenkor gyorsan, nagy nyomás alatt kell döntéseket hoznia, illetve a rajta kívül a jármüben/jármüvekben ülö többi katona életéért is ő felel. Egy autonóm gépkocsikból álló konvoj esetén csak az elsőben ül vezető vagy a jövőben már egyikben sem. Ez megkönnyíti a döntéshozatalt, mert nincs emberélet veszélyben, a felelős személyek biztonságos távoli helyről irányíthatják a konvoj mozgását. Továbbá a döntést a jármü precíz szenzorai, kamerái és érzékelő rendszere alapján hozhatják meg, míg egy nyomás alatt lévő jármüvezető valószínüleg csak a saját szemére hagyatkozik, így nem biztos, hogy az optimális megoldási változatot hajtja végre.

Függetlenül attól, hogy civil, vagy katonai egy jármü, előfordulhat, hogy közlekedési balesetet szenved, vagy esetleg okoz annak vezetője. A szárazföldi közlekedési balesetek több mint kilencven százalékát emberi hiba okozza. Egy-egy ilyen gondatlanságból, figyelmetlenségből vagy fáradság miatt bekövetkezett baleset jelentősen befolyásolja a katonai feladatok sikerességét. Az autonóm rendszerekben rendelkezésre álló megoldások viszont nagymértékben elkerülhetővé teszik az ilyen kockázatos helyzetek kialakulását. A katonai alkalmazás sajátossága, hogy többször fordulnak elő olyan esetek, amelyek során a jármű nem egy véletlen baleset, hanem egy szándékos támadás következtében sérül meg, borul fel. A szárazföldi közlekedést érintő, leggyakrabban előforduló katasztrófákat IED-k² okozzák. Az ellenséges támadások célpontjai legtöbbször a logisztikai szállítmányok. Ha a tehergépjárművek egy részét automatizált vezetési rendszerrel tudnánk mozgatni, már számtalan életet menthetünk meg. Ez kétféle módon is megvalósítható: egyrészt az ember fizikai jelenlétének hiánya által, illetve az autonóm jármüvekben rendelkezésre álló fejlett érzékelő, felderítő berendezésekkel.

\section{A VEZETŐ NÉLKÜLI KATONAI SZÁLLÍTÓ JÁRMŰVEK ALKALMAZÁSI LEHETŐSÉGEI MŰVELETI TERÜLETEKEN}

Összehasonlítva a vezető nélküli szállító jármủvek honi területen végzett és a katonai missziós müvelet során történő felhasználását, a meghatározó különbség a kettő között az a fenyegetettség, veszély, amely ezen járművekre és a rajtuk szolgálatot teljesítő katonákra leselkedik a müveleti területeken. „A NATO afganisztáni és az iraki müveletek tapasztalatai is azt mutatják, hogy az aszimmetrikus hadviselésben a harcos katona és a kiszolgáló katona közötti különbségek eltüntek. Mindenki, mindenhol célpont, ...” - írja Papp Gyula. [2; 40. o.]

Ahogyan Michael D. Griffin ${ }^{3}$ tájékoztatásából kiderül, a harci zónákban elesett amerikai áldozatok több mint fele a kritikus szállításokat végző katona volt. [3] Vezető nélküli járművek alkalmazásával viszont a katonákat meg lehetne óvni a felesleges veszélyektől egyszerüen

\footnotetext{
${ }^{2}$ Improvised Explosive Devices. Házi készítésü, improvizált robbanó eszközök, melyeket olyan elemekből állítanak össze, melyet a legtöbb háztartásban fel lehet lelni.

${ }^{3}$ Az Amerikai Egyesült Államok Védelmi Minisztériumának technológiai vezetője.
} 
azzal, hogy fizikailag távol maradnak az ilyen helyzetektől. Ez a szemlélet tükröződik az Egyesült Allamok vezető nélküli jármúvekre vonatkozó stratégiájából is. [4] A világ egyik legnagyobb hadseregével rendelkező és az autonóm jármütechnológiai fejlesztésekben élen járó országként érdemes figyelemmel kísérni elképzeléseiket, a megvalósult tesztek eredményeit és levonni belőlük a tanulságokat.

A rövid (2017-2020) és a középtávú (2021-2030) terveik között szerepel a szituációs tudatosság, vagyis a helyzetfelismerés javítása, a katonák fizikai terhelésének csökkentése, hogy energiáikat a küzdelemre tartalékolhassák, valamint a katonai szállítások kockázatainak csökkentése vezető nélküli jármüvek alkalmazásával. Csak a hosszú távú (2031-2040) elképzelésekben szerepel az autonóm technológia alkalmazása a harci tevékenységek támogatására, szemben Oroszországgal, amelynél ez utóbbi élvez prioritást. [5] A tervekből látható, hogy a hadsereg sokkal elfogadóbb és nyitottabb, kevesebb aggállyal bír az autonóm jármüveket illetően, mint a civil szféra, ahol az önvezető autók bekövetkezett balesetei miatt már sokkal óvatosabban fogalmaznak a technológia jövőjét illetően. Az amerikai katonai vélemény ugyanis az, hogy olyan veszélyes környezetben, mint például egy háború, érdemes bizonyos kockázatokat vállalni azért az előnyért cserébe, hogy megvédjék a katonákat. [3]

A vezető nélküli közúti szállító járművek katonai műveletek során történő alkalmazásánál a legfontosabb tényezö, amelyet figyelembe kell venni, az a veszély, amit az aknák és improvizált robbanóeszközök jelentenek. A védekezést a szállítási útvonalak állandó ellenőrzés alatt tartása, a szállító konvojok kísérése, illetve maguknak a járműveknek a megerősítése jelenti. Azonban ezek a megoldások több hátránnyal is járnak. Az ellenőrzés és a védelem jelentős élőerőt és felszerelést igényel, elvonva ezeket a harcoktól, ezen kívül plusz költségekkel jár. Tovább növeli a kiadásokat a jármüveket a robbanások hatásaitól védő páncélzat, ami ráadásul a szállítható rakomány tömegét is csökkenti, ez pedig újabb költségeket generál, hiszen több jármü szükséges ugyanannyi áru elszállításához. Emellett pedig számolni kell a müveleti területek korábban már említett földrajzi, infrastrukturális jellemzőivel, amelyek mindenképpen megfelelő terepjáró-képességgel rendelkező - tehát szintén nem olcsó - járműveket igényelnek.

A fenti biztonsági és gazdasági felvetésekre egyaránt választ jelenthet a vezető nélküli jármüvek alkalmazása a katonai szállításokban a müveleti területeken. A szállítási feladatokban - ilyen körülmények között - nem célszerü egyetlen jármü útnak indítása, a vezető nélküli megoldások közül talán csak a távirányítás merülhet fel ilyen esetben. A védelmi és taktikai megfontolások több tehergépjármü együtt, oszlopban történő közlekedése mellett szólnak. Az autonóm technológia szempontjából itt is a civil szférában már kipróbált platooning rendszer alkalmazása a célravezető, amelyet megerősít, hogy a külföldi fejlesztések és tesztelések is ebben az irányban zajlanak.

A technológia lényege, hogy a konvoj tagjai az elől haladó járművet követik és annak mozgásaira, cselekvéseire reagálnak, alkalmazkodnak azokhoz. Úgy teszik ezt, mint ahogyan a katonák követik a szakaszparancsnokukat. (1. számú kép) 


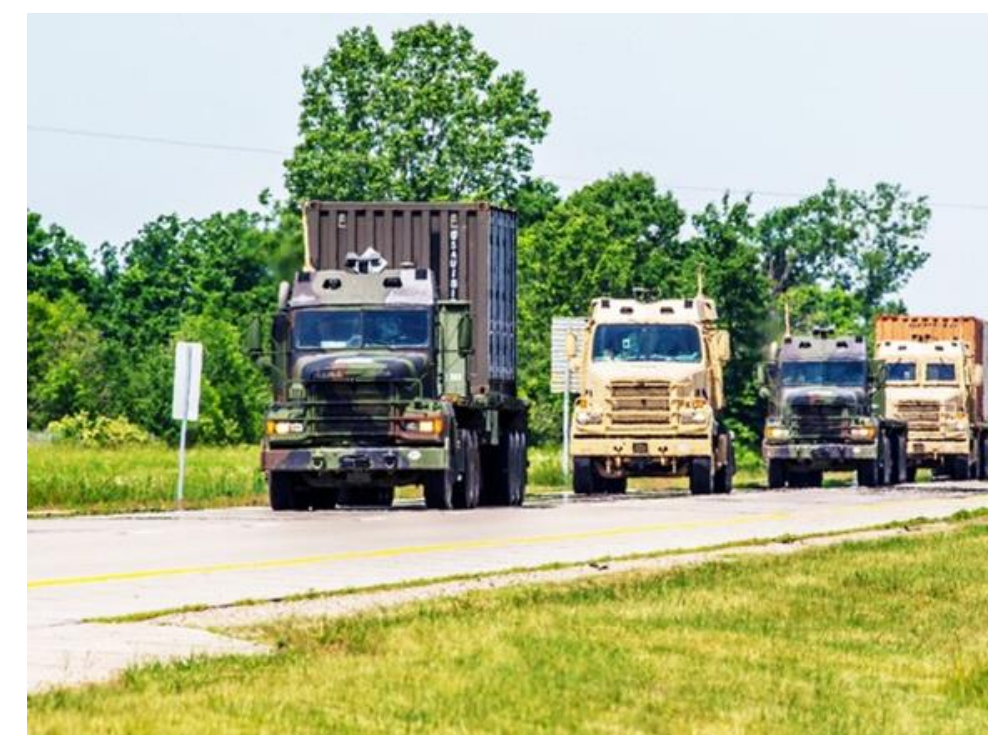

1. kép Platooning rendszerrel müködő katonai jármükonvoj Michigan-ben. [6]

A platooningnak több fajtája is szóba jöhet:

- A jármüvek egy elől haladó, ember által irányított jármüvet követnek. Ilyenkor a többi jármü közlekedhet teljesen ember nélkül vagy ezekben is tartózkodik egy katona, akinek a feladata az esetleges beavatkozás, az örködés és a támadások elleni védelem lehet.

- Az önvezető gépkocsi egy előtte haladó személy mozgását követi.

- A követö jármüveket több-kevesebb távolságból, távirányítással müködtetik.

- A konvojban lévő minden jármü teljesen autonóm módon üzemel.

A technológia mai fejlettségi szintjét (és fejlődési ütemét) tekintve, ez utóbbi megoldásra nem lehet a közeli jövőben reálisan számítani a müveleti területeken. Az első változatra viszont már most is vannak ígéretes teszteredmények. Az amerikai hadsereg ezek alapján az Automatizált Földi Utánpótlás (AGR) program keretében 2022-től számol egy vezető jármüből és pilóta nélküli gépkocsikból álló konvojok tényleges - tehát nem tesztüzemü közlekedésével. [7]

A vezető nélküli szárazföldi tehergépjárművek, az úgynevezett CUGV-k ${ }^{4}$ fejlesztésére irányuló program 2010-ben vette kezdetét annak meghatározására, hogy a vezető nélküli jármütechnológia hogyan illeszthető az amerikai tengerészgyalogság taktikai jármüveibe, a katonák veszélyeztetettségének csökkentésére és a logisztikai konvojok üzemeltetésének egyszerüsítésére. [8] Az Oshkosh Defence vállalat közremüködésével megvalósuló programban 2012-ben próbálták ki önvezető jármüvek beillesztését hagyományos módon vezetett gépjármüoszlopba, amelynek tapasztalatai igen pozitívak voltak. [9]

Az alkalmazott technológia lényege a TerraMax rendszer, amely a legtöbb taktikai kerekes jármübe integrálható. A TerraMax UGV csomag az Oshkosh Command Zone 5 elektronikájából, egy szenzorcsomagból és egy fejlett kezelőegységből $\left(\mathrm{OCU}^{6}\right)$ áll. A technológiával felszerelt járművek a képesek egy vezető jármüvet követve közlekedni egy konvojban, de a gyártó szerint teljesen autonóm módon is működtethetők. [10] A rendszer több érzékelési módot használ: a

\footnotetext{
${ }^{4}$ Cargo Unmanned Ground Vehicles

${ }^{5}$ Integrált vezérlő és diagnosztikai rendszer

${ }^{6}$ Operátorvezérlő egység
} 
terep és az akadályok elemzésére szolgáló elsődleges érzékelő a $360^{\circ}$-ban müködő nagy felbontású (HD) lézerradar (LADAR). Emellett kis és nagy hatótávolságú radarok szolgálják a jármü környezetének felderítését, széles látószögü, nagy dinamikus tartományú és infravörös kamerák segítik a környezet vizuális ellenőrzését, például egy távoli irányításhoz, valamint az éjszakai müködéshez.

A navigációt és helymeghatározást a GPS és inerciális navigációs rendszer együttes alkalmazása biztosítja, így ha korlátozott a GPS jel, az INS továbbra is kiszámíthatja a pozíciót és a szöget az elveszett GPS-jelek időtartama alatt. [11] Az alkalmazott érzékelőket az 2. kép mutatja részletesen.

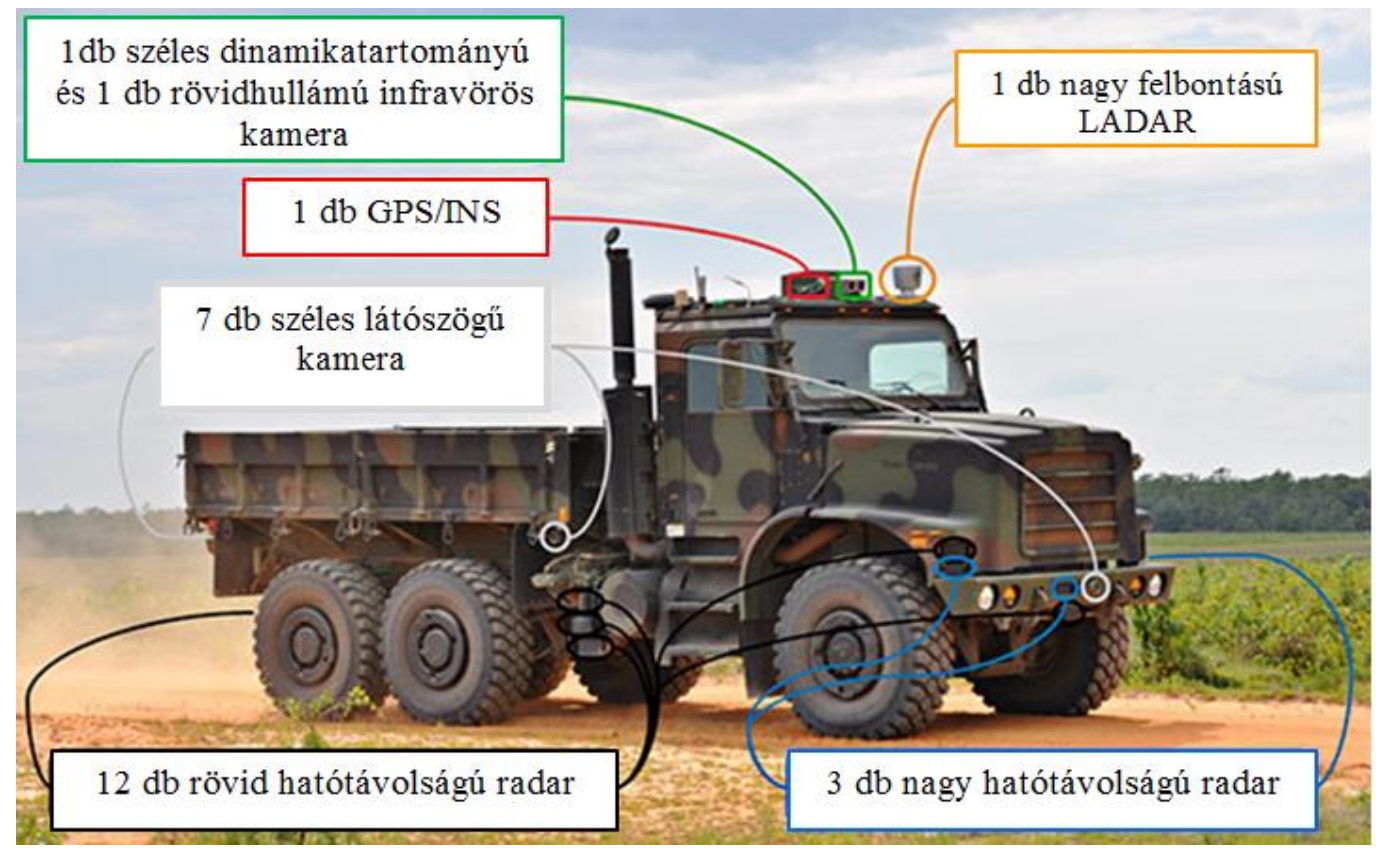

2. kép A TerraMax rendszerrel ellátott vezető nélküli szállító jármü szenzorai [11]

A különböző szenzorok különféleképpen „látják” a környezetet, ami jelentősen eltér attól, amilyen képet az emberi szem érzékel (illetve róla az agy előállít). A TerraMax érzékelői esetén például a 3. képnek megfelelő jelenik meg a kijelzőn.

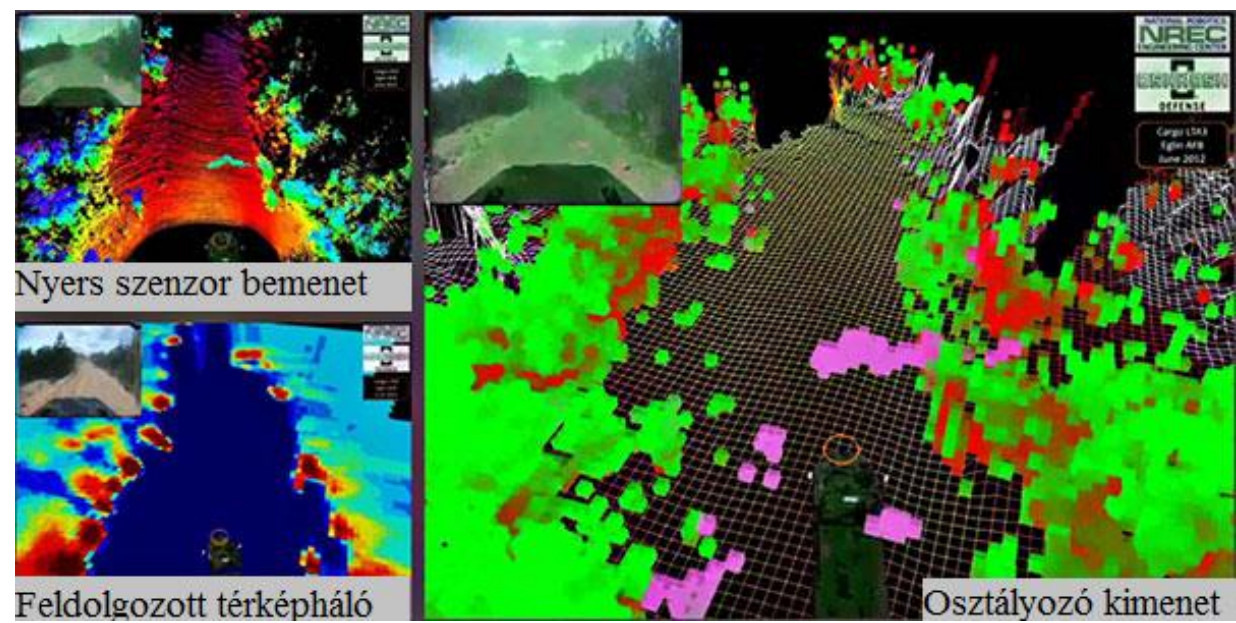

3. kép A TerraMax érzékelési rendszere [11]

Összefoglalva a technológia előnyeit, a következőket lehet elmondani:

- a moduláris kialakítás miatt gyorsan telepíthető hagyományos jármüvekre is, 
- többféle érzékelőt használ, amelyek kiegészítik egymást,

- fejlett számítógépes rendszer,

- felhasználóbarát kezelői felület,

- kezelése könnyen elsajátítható.

De miért csak a fejlesztésnél-tesztelésnél tart a folyamat, miért kell olyan sok évet várni a tényleges alkalmazásra, ha annyi előnye van az autonóm technológiának? A válasz a müveleti környezet összetettségében és kiszámíthatatlanságában rejlik. Bár, mint láttuk, a katonai felhasználásnál vállalhatók bizonyos kockázatok, de ma még annyi a bizonytalanság technológia alkalmazásával kapcsolatban, hogy az késlelteti az általános elterjedésüket.

Az eddigieket alapul véve az a következtetés vonható le, hogy a vezető nélküli szállító jármüvek katonai célú alkalmazásának - a békeidőszaki felhasználáshoz hasonlóan - müveleti területen is a vegyes vagy teljesen autonóm jármüvekből álló konvoj a legreálisabb módja. Az ilyen katonai szállító gépjármüoszlopok alapvető logisztikai feladatokat képesek ellátni, sok katona életét megőrizve. Ugyanakkor a jármüveknek többet kell tudniuk annál, mint hogy egyszerüen követik egymást. Alkalmasnak kell lenniük a városi és a mostoha útviszonyok közötti közlekedésre, akkor is, ha por, sár, hó zavarja az érzékelöiket. Képesnek kell lenniük rugalmasan váltani a manuális, a távolról irányított és a teljesen autonóm üzemmód között. Vagyis a müködésük a különböző technológiák együttes müködésétől függ, ezét a kutatásoknak is a rendszer egészére kell összpontosítani. Jól tükrözik ezt az aktuális fejlesztések, hiszen a tervezők-gyártók is rendszerben fejlesztik saját megoldásaikat.

A modern katonai müveletek kulcsfontosságú tényezője a logisztika, a készletek feltöltésének, az utánszállításoknak a gyorsasága. A harcoló alakulatok hiába haladnak erőltetett ütemben, ha a logisztikai utánpótlás nem ér el hozzájuk kellő időben. Ennek biztosítására, valamint annak érdekében, hogy a logisztikai utánpótlások végrehajtásához ne vonjunk el nagy létszámú erőket a harci tevékenységektől az autonóm jármüvek alkalmazását érdemes megfontolni. A szállítmány és a kísérő katonák védelme érdekében mindenképpen célszerü, ha a gépjármủoszlop előtt egy - szintén autonóm - felderítő, mentesítő jármü halad, amely az aknák és IED-k észlelésével és megsemmisítésével növeli a szállítmány, müvelet biztonságát. $^{7}$

\section{A VEZETŐ NÉLKÜLI KÖZÚTI SZÁLLÍTÓ JÁRMÜVEK KATONAI FELHASZNÁLÁSÁNAK ELŐNYEI ÉS KORLÁTAI}

Mint minden technológiának így a vezető nélküli jármütechnológiának is megvannak a maga előnyei és hátrányai vagy éppen az alkalmazást limitáló tényezői. Azt már bizonyított, hogy a civil szférában milyen pozitív hatásai vannak az autonóm szállító jármüveknek többek között a környezetvédelemre és a biztonságra. A katonai alkalmazás területén azonban ezeken a szempontokon túl más területeket is meg kell vizsgálni.

A vezető nélkül működő szárazföldi járművek a kor legkorszerübb, legprecízebb müszereit, berendezéseit használják. Az alkalmazás elterjedéséhez azonban folyamatos kutatásokra, fejlesztésekre és oktatásra van szükség. Ezeknek viszont pénzügyi vonzata van. Mint minden modern technológiának, így az autonóm jármütechnológiának is a bevezetés kezdetén igen nagy a beszerzési költsége. Azonban minél népszerübbé válik egy technológia vagy termék, úgy csökkennek a beszerzési kiadások is. Ez a megfontolás érvényesül például az Egyesült Államok vezető nélküli szárazföldi jármüvekkel kapcsolatos kiadásainak vonatkozásában. Az USA

\footnotetext{
${ }^{7}$ Ez a hagyományos konvojok esetében is így történik.
} 
Kormánya nem rendelkezik olyan kutatás-fejlesztési programmal a katonai autonóm járművek tekintetében, mint ami a civil szektor fejlesztéseit illeti. A civil szektorban a piaci verseny ösztönzi az új ötleteket és ezzel a kutatási és fejlesztési beruházásokat. Ezért az amerikai Kormány külön nem költ erre, hanem amint egy technológia elért egy elfogadható szintet a katonai alkalmazáshoz, akkor megvásárolja azt. [1; pp. 17.] Ez a tendencia jól megfigyelhető az 1. számú diagramon, amely az Amerikai Egyesült Államok Védelmi Minisztériuma által a 2014-2018 közötti időszakra - a vezető nélküli szárazföldi jármüvekkel kapcsolatos kutatásra, fejlesztésre, tesztelésekre és kiértékelésekre (RDT\&E), valamint a beszerzésekre - szánt összeget mutatja. Látható, hogy míg 2015-ben 19,1 millió dollár (USD) volt a tervezet, 2018ra ez visszaesik 10,6 millió dollárra. Ezzel szemben a beszerzésre szánt összegek jóval meghaladják a saját kutatások tervezett kiadásait, sőt várhatóan növekednek, a tervek szerint 2018-ra meghaladják a 70 millió dollárt. [12; pp. 80.]

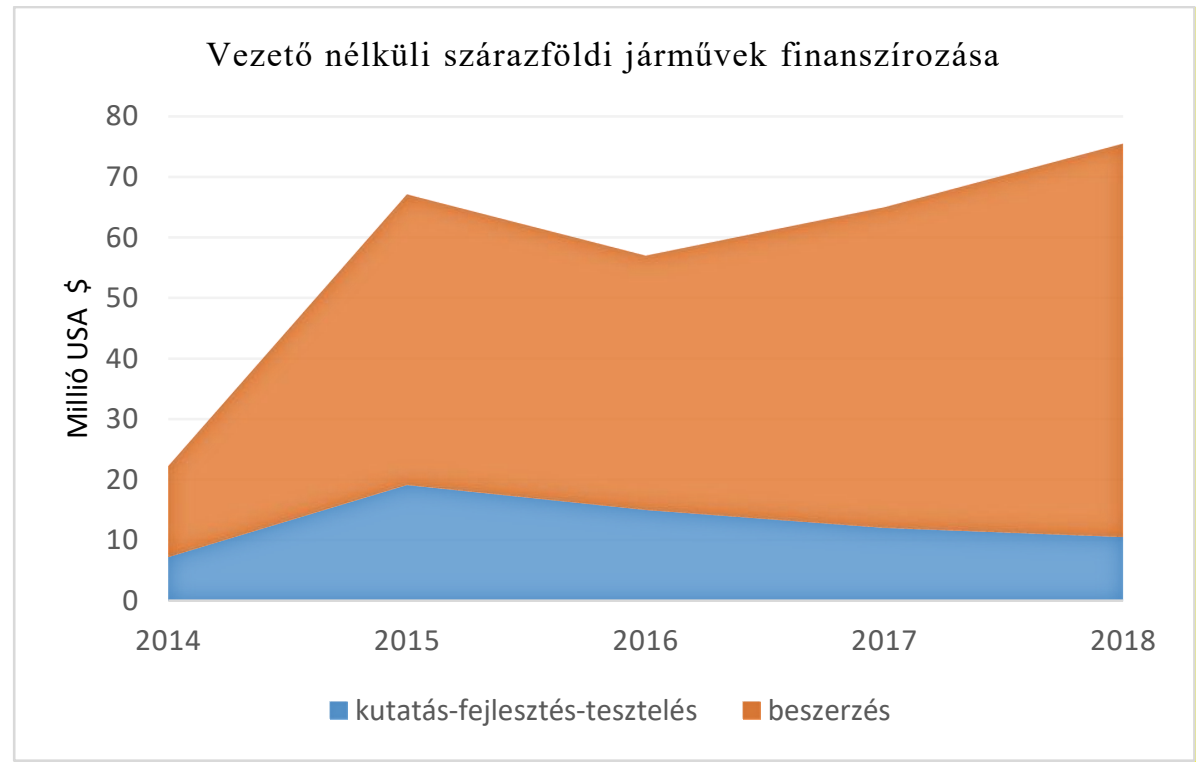

1. diagram A vezető nélküli katonai szárazföldi járművek tervezett finanszírozása az USA-ban ${ }^{8}$

Az autonóm jármütechnológia - újszerüségéből adódóan - még rendkívül drágának mondható, de várhatóan el fog érni egy alacsonyabb költségszintet. A Loup Ventures befektetési tanácsadó és elemző cég szerint - a 2016-os adatokat alapul véve -, az eladott pilóta nélküli szárazföldi katonai jármüvek száma 2025-re várhatóan megháromszorozódik, ami 450 millió dolláros piaci lehetőséget jelent. [13] Egy hagyományos gépjármüvet üzemeltető katona afganisztáni bevetéséhez 750000 és 1250000 USD dollár közötti összegre van szükség évente. Ez magába foglalja az oda,- és visszaút költségeit, valamint minden egyéb, a kint tartózkodás alatt felmerülő kiadást. A Védelmi Minisztérium a müveletekre és a karbantartásra fordított összegek után a katonai személyzetre költi a legtöbbet. [1; pp. 26-27.]

Az adatok alapján, hosszabb távon jobban megéri a vezető nélküli jármüvet használni, mert kevesebbe kerül, mint az ugyanazon feladat ellátásához szükséges katonákkal kapcsolatos kiadások. A jármüvel kapcsolatos költségeket csökkenti a üzemanyag-hatékonyság is, amelyet a tehergépjármü müködésének számítógépes irányítása tesz lehetővé, például a legrövidebb út megtervezése, a megfelelő sebesség kiválasztása, az ideális jármü-távolság tartása által. Szintén

\footnotetext{
${ }^{8}$ A hivatkozott forrás [10; pp. 80.] alapján saját szerkesztés.
} 
gazdasági szempont, hogy katonai szállítójármüvek amúgy sem olcsók és rengeteg sérül meg, pusztul el a már említett balesetek, támadások, robbanóeszközök miatt. Az autonóm járművekben levő korszerü eszközök segítenek ezeket megakadályozni, ezzel pedig megtakarítást eredményeznek a javítási költségeknél, illetve nem kell annyi új jármüvet beszerezni. Ugyanakkor nem szabad elfelejteni azt sem, hogy maga az autonóm jármüirányítási technológia is nagyon sokba kerül, ami minden általa elérhető megtakarítás ellenére jelenleg még gátat szab elterjedésének. Ide tartozik, hogy egy vezető nélküli jármü számos drága berendezést, eszközt tartalmaz mind a jármü külső felületén elhelyezve, mind annak belsejében. Ezeknek a meghibásodása, sérülése esetén a javítási, pótlási költségek többszörösei lehetnek a hagyományos jármüveket érintő javítási költségeknek. Illetve az autonóm gépjármüvekben alkalmazott összetett, bonyolult technikáknak nagyobb a meghibásodási valószínűség, mint az egyszerü szerkezeteknek. Ez a komplikáltság a javítási munkák körülményességét is eredményezi, ennek további idő és pénzbeli vonzata van.

Az emberiség kezdete óta nem volt még olyan időszak, hogy a Föld valamely pontján ne dúlt volna valamilyen háború vagy fegyveres konfliktus. Ez nagy valószínüséggel a jövőben is így lesz, s amíg háború van, addig veszteség is mindig lesz. Ma már léteznek olyan precíziós, nagy távolságú fegyverek, amelyekkel akár el is kerülhető, hogy a katonák közvetlen vegyenek részt a harcban, de még nem tartunk ott, hogy teljesen elhanyagolható legyen a bevetendő emberek száma. A vezető nélküli gépjármüvek segítségével viszont lecsökkenthetjük azoknak a számát, akik a veszélyzónákban kockáztatják az életüket. Minél kevesebb a személyzete egy konvojnak, annál kisebb az esélye, hogy megsérül, meghal valaki. Ha vezető nélküli gépjármüveket alkalmazunk, akkor csupán a technológiát, a müszereket és berendezéseket tesszük ki veszélynek. Ezek elvesztése, megrongálódása természetesen magas pénzügyi károkat okoz, de még mindig nem hasonlítható össze azzal, ha egy katona veszti életét az incidensben. Arról nem beszélve, hogy az emberi élet elvesztése is súlyos anyagi vonzatokkal jár.

A katonák életének védelme napjainkra felértékelődött. Bár a háborúk mindig is emberáldozattal járnak, egyre nagyobb a társadalmi nyomás annak érdekében, hogy minél kevesebb katona veszítse életét a világon. Mindamellett, hogy a katonai vezetők számára is ez a legfontosabb cél, ők a katonákkal, mint humán erőforrással is számolnak. A professzionális hadseregek korában szakmailag jobban felkészültek, de kisebb létszámúak a haderők, éppen ezért van nagy jelentősége a vezető nélküli technológia alkalmazásának a katonák egyes tevékenységeinek kiváltására.

Az autonóm jármüvek alkalmazása müveleti területen jótékony hatással lehet az adott misszió társadalmi támogatottságára is. A legtöbb országban, ha külföldön szeretnék bevetni a hadsereget, akkor a felelős szervnek (Kormány, Országgyülés, stb.) előbb el kell azt fogadnia. A vezető nélküli jármüveknek köszönhetően egy-egy ilyen feladatra kevesebb katona is elég, így szívesebben támogatja a közvélemény is, tudván, hogy emberi élet nem kerül kockáztatásra.

Az előzőekben láthattuk, hogy az autonóm jármütechnológia számos előnyt rejt magában, pozitív tulajdonságain túl azonban kockázatai is vannak. Az autonómia csak annyit jelent, hogy a vezető ülésben nincs ránk szükség, de a technológiát, az elengedhetetlen eszközöket mind emberek tervezik és ez már önmagába foglalja a hiba lehetőségét. Singer 2009-es kiadású könyvében úgy véli, hogy egy automatizált rendszer minél nagyobb szintű autonómiát ér el, annál nagyobb a kockázata egy esetleges meghibásodásnak. [14; pp. 195.]

A vezető nélküli járművek müködése a korszerü számítógépes rendszereken alapszik. Ezek az informatikai hálózatok mind rendkívül sebezhető elemei az automatizált vezetési rendszereknek. A legnagyobb veszélyt a kiber támadások jelentik. Kiber támadásnak nevezzük azokat a „szándékos cselekményeket, melyeknek célja, hogy megváltoztassa, megzavarja, becsapja vagy tönkre tegye egy számítógépes rendszer vagy hálózat müködését.” [15; pp.1.] Mennyire bonyolult hozzáférni egy autonóm jármű számítógépes bázisához és eltéríteni azt? A válasz meglepő: nem igazán okoz gondot senkinek, ugyanis elérhető az interneten. Nils Ole 
Tippenhauer, svájci tudós és kollégái megosztották ezzel kapcsolatos ismereteiket a nagyvilággal, két héttel később pedig az irániak ezek alapján sikeresen hozzájutottak a CIA ${ }^{9}$ egyik autonóm légi járművének GPS adataihoz és földre irányítva azt, értékes információkhoz jutottak hozzá. Ilyen könnyen megtörténhet bármilyen vezető nélküli jármüvel, és ha ez ráadásul müveleti területen következik be, akkor akár könnyen eldöntheti egy fegyveres konfliktus kimenetelét is. [16; pp. 66-67.]

\section{A TECHNOLÓGIA ALKALMAZÁSÁNAK JÖVŐJE}

Az automatizált vezetési rendszerek használatának bevezetése a fegyveres szerveknél forradalmi változásokat hozhat el. Azonban ott még nem tart a technológia, hogy egy katonai mủveletben csak autonóm jármủvek vegyenek részt, ott lesznek a hagyományos gépjármüvek, a gyalogos katonák, a civil jármüvek, személyek és a légi, vezetővel müködő vagy vezető nélküli jármüvek. Az autonóm szárazföldi gépjármüveknek tehát egy igen komplex környezetben kell tudniuk tájékozódni, feladatot végrehajtani úgy, hogy az imént felsoroltakkal mind együtt tudjanak müködni. Az automatizált vezetési rendszerek alkalmazásának elterjedéséhez a szárazföldi, katonai gépjármüvekben nem elegendö csupán a járművek közti együttmüködés. A külföldi müveletek többségét a hadseregek legtöbbször multinacionális környezetben hajtják végre, így nélkülözhetetlen az összefogás az autonóm jármütechnológiát felhasználó nemzetek között. is. Ahhoz, hogy ez megvalósulhasson, több program és nemzetközi együttmüködési megállapodás is létrejött már.

A legtöbb együttműködés célja a technológiai újítások kapcsán az információk megosztása, megvitatása egymással. Ennek leginkább gazdasági okai vannak, ugyanis nem kedvező, ha a technológia duplikálódik, így felesleges erőforrások vesznek kárba. Az adatok kölcsönös biztosítása müködik többek közt a NATO-ban, de ilyen kooperáción alapul például a Foreign Military Sales (FMS) nevü program is. Az utóbbi keretein belül a partner hadseregek tudományos cikkeikhez, kiadványaikhoz engednek hozzáférést a koalíció többi tagjának. [17; pp. 114.] Az egyik legújabb partnerség az Észtország vezetése alatt, Finnország és Lettország közremüködésével megszületett európai együttmüködés. A projekt keretein belül egy pilóta nélküli földi jármüvet, önálló vezérlőrendszert, internetes védelmi megoldást és integrált érzékelő-hálózatot fejlesztenek ki. A program - amely iránt Németország, Franciaország és Belgium is érdeklődik - 2019-ben kezdődik el, az Európai Védelmi Alap 30-40 millió eurós támogatásával, továbbá a résztvevő országok is hozzájárulnak a megvalósítás sikeréhez. [18]

A nemzetközi tendenciák azt mutatják, hogy a világ hadseregei jelenleg is és a jövőben is sok figyelmet, energiát és pénzt fordítanak a legkülönfélébb autonóm eszközök, vezető nélküli járművek, harci robotok kifejlesztésére. A katonai tehergépjármüvek automatizálása viszont kifejezetten az a terület, ahol a katonaság a civil fejlesztésekre támaszkodik, azokat veszi át, így forradalmi katonai újításokra itt nem számíthatunk.

\section{ÖSSZEGZÉS}

Az autonóm jármütechnológia katonai felhasználásának számos pozitív hatása van. A technológia felhasználásával olyan jövőbe mutató szempontok elégíthetők ki, mint a gazdaságosság, környezetkímélés és a biztonság. Ezen kívül az emberi tényező teljes vagy részleges kivonásával megvalósíthatók a katonai müveletek nézőpontjából nagy jelentőségü változások: csökkenthető a katonai szállításokhoz köthető áldozatok száma, nő a müveleti rugalmasság és jelentősen megrövidül, leegyszerüsödik a döntéshozatali folyamat.

9 Az Amerikai Egyesült Államok egyik hírszerző ügynöksége. 
A létező autonóm járműkonstrukciók egyértelmüen azt bizonyítják, hogy a vezető nélküli járművek már nem a jövőt jelentik, hanem a jelent. Az autonóm technológia hozhatja el a megoldást a napjaink fegyveres konfliktusait jellemző aszimmetriára és a folyamatosan változó, bizonytalan környezetből eredő kihívásokra. Azonban egy technológia elterjedéséhez mindig szükség van a társadalmi támogatottságra. A robottechnológia kifejezetten harci feladatokra való felhasználása olyan etikai kérdéseket vet fel, amelyeket először a nemzetközi közösségnek kell megvitatnia és a szabályokat lefektetnie. Ezzel szemben a technológia katonai szállításokban való alkalmazása nem vált ki ilyen mértékủ társadalmi és jogi aggályokat, hiszen itt a gazdasági és taktikai szempontokat messze megelőzi az emberi élet védelme.

A vezető nélküli jármüvek, eszközök forradalmi jelentősége nem csak abban áll, hogy távol tartja az embert a veszélyes szituációktól, hanem megváltoztatja a katonák egy részének szerepét és feladatait. Mindezek a lehetőségek új kihívásokat is jelentenek, hiszen fel kell készülni az autonóm technológia használatára. Ebben a felkészülésben nekünk sem szabad lemaradnunk. Bár a vezető nélküli szállító jármüvek alkalmazásának nincs realitása a közeljövőben a Magyar Honvédségben, de a szövetségesi kötelezettségekből eredő feladatok végrehajtása során mi is kapcsolatba kerülhetünk vele. Ezért a hatékony együttmüködés biztosítása érdekében fontos lenne, hogy a katonai felsőoktatásban megjelenjen a vezető nélküli technológiával kapcsolatos ismeretek átadása.

\section{FELHASZNÁLT IRODALOM}

[1] GREEN, D. A.: The Future of Autonomous Ground Logistics: Convoys in the Department of Defense. U.S. Army. School of Advanced Military Studies United States Army Command and General Staff College Fort Leavenworth, Kansas, 2011.

[2] PAPP GY.: A magyar honvédség békefenntartó müveletekre kijelölt alegységeinek felkészítése. PhD értekezés, Budapest, 2008. 40. o.

[3] MURISON, M.: Pentagon: Military will have self-driving vehicles before public. 2018. https://internetofbusiness.com/pentagon-military-self-driving-vehicles/ (Letöltve: 2018. 06. 05.)

[4] THE U.S. ARMY: Robotic and Autonomous Systems Strategy. 2017. https://www.tradoc.army.mil/Portals/14/Documents/RAS_Strategy.pdf (Letöltve: 2018. 07. 17.)

[5] GAO, C. (2018): Russia vs. America: Which Nation Will Dominate Unmanned Ground Vehicles? The National Interest. https://nationalinterest.org/blog/buzz/russia-vs-americawhich-nation-will-dominate-unmanned-ground-vehicles-28407 (Letöltve: 2018. 07.20.)

[6] MARSHALL, A. : The army's self-driving trucks hit the highway to prepare for battle 2016. https://www.wired.com/2016/07/armys-self-driving-trucks-hit-highway-preparebattle/. US ARMY TARDEC. (Letöltve: 2018.05.06.)

[7] FREEDBERG, S. J.: Army wants 70 self-driving supply trucks by 2020. 2017. https://breakingdefense.com/2018/08/army-wants-70-self-driving-supply-trucks-by2020/ (Letöltve: 2018. 09. 21.)

[8] OSHKOSH DEFENSE: U.S. Office of Naval Research continues Cargo UGV project with Oshkosh Defense. https://oshkoshdefense.com/news/u-s-office-naval-researchcontinues-cargo-ugv-project-oshkosh-defense/ (Letöltve: 2018. 09.11.) 
[9] HONVÉDELEM.HU: Vezető nélküli tehergépjárműveket tesztel az amerikai tengerészgyalogság. https://www.honvedelem.hu/cikk/33482/vezeto-nelkulitehergepjarmuveket-tesztel-az-amerikai-tengereszgyalogsag$\underline{\text { \&sa}=U \& e i=H J t F U M u F K 8 b 54 Q T W v Y H Q A Q \& v e d=0 C C E Q q Q I w A j i V A w \& u s g=A F Q j ~}$ CNFWnhbZ86cI8b5pspQQsxVQWeAboQ (Letöltve: 2018.09.12.)

[10] OSHKOSH DEFENSE: TerraMax - Unmanned Ground Vehicle Technology. https://oshkoshdefense.com/components/terramax/ (Letöltve: 2018. 07. 03.)

[11] BECK, J.: Tomorrow's driverless convoy on the road today. 2016. http://gpsworld.com/tomorrows-driverless-convoy-on-the-road-today/ (Letöltve: 2018. 10. 03.)

[12] JONES, C. D.: An analysis of the defense acquisition strategy for systems unmanned (Master's thesis). Monterey, CA: Naval Postgraduate School. (2014, March). pp. 80. https://apps.dtic.mil/dtic/tr/fulltext/u2/a607870.pdf (Letöltve: 2018. 10. 24.)

[13] MURPHY, A.: Military: Robotics Outlook 2025.2017. https://loupventures.com/military-robotics-outlook-2025/ (Letöltve: 2018. 10. 30.)

[14] SINGER, P. : Wired for war. New York, NY: Penguin Press. 2009. pp. 195.

[15] OWENS, W.; DAM, K.; LIN, H. (2009): Technology, policy, law and ethics regarding U.S. acquisition and use of cyberattack capabilities. Washington DC, National Academies Press, 2009. pp. 1.

[16] ERGENE, Y.: Analysis of unmanned systems in military logistics.: Naval Postgraduate School, Monterey, California, 2016. pp. 66-67. https://apps.dtic.mil/dtic/tr/fulltext/u2/1030852.pdf (Letöltve: 2018. 08. 27.)

[17] UNITED STATES OF AMERICA, DEPARTMENT OF DEFENSE: Unmanned Systems Integrated Roadmap. FY2013-2038. Approved for Open Publication. Reference Number: 14-S-0553. pp. 114. https://apps.dtic.mil/dtic/tr/fulltext/u2/a592015.pdf (Letöltve: 2018. 08. 24.)

[18] iHLS - Israel's Homeland Security: European Collaboration in UGV Development. https://i-hls.com/archives/84713 (Letöltve: 2018. 09. 27.) 